\title{
PENGARUH STORE ATMOSPHERE DAN KERAGAMAN PRODUK TERHADAP KEPUTUSAN PEMBELIAN PADA CHANDRA MINI MARKET WAY HALIM
}

\author{
Defrizal $^{1}$, Fauzi Febriansyah ${ }^{2}$ \\ Fakultas Ekonomi, Universitas Bandar \\ Lampung
}

JI. Z.A Pagar AIam No. 26 Labuhan Ratu, Kedaton, 35142, Bandar Lampung Indonesia

Email:

Defrizal@ubl.ac.id

Faauzyy@gmail.com

\begin{abstract}
ABSTRAK
Tujuan dari penelitian ini adalah Untuk menganalisis pengaruh store atmosphere dan keragaman produk terhadap keputusan pembelian. Populasi penelitian ini adalah konsumen Chandra mini market Way Halim yang memiliki populasi berjumlah 3922 dan teknik sampling rumus slovin, maka ditentukan sampel dengan jumlah 98 orang responden. Sumber data adalah kuisioner online kepada konsumen chandra mini market Way Halim. Metode pengumpulan data yaitu data primer yang dilakukan dengan cara observasi, studi dokumentasi dan kuesioner.

Hasil penelitian ini adalah Store Atmosphere mempunyai pengaruh positif signifikan terhadap Keputusan Pembelian pada Chandra Mini Market Way Halim. Artinya Store Atmosphere pada Chandra Mini Market Way Halim sudah baik. Keragaman Produk mempunyai pengaruh positif signifikan terhadap Keputusan Pembelian pada Chandra Mini Market Way Halim. Artinya Keragaman produk Chandra Mini Market Way Halim sudah baik. Store Atmosphere dan Keragaman Produk mempunyai pengaruh positif dan signifikan secara bersama-sama terhadap Keputusan Pembelian pada Chandra Mini Market Way Halim. Artinya Store Atmosphere dan Keragaman Produk pada Chandra Mini Market Way Halim sudah baik.
\end{abstract}

Kata Kunci: Store Atmosphere, Keragaman Produk, dan Keputusan Pembelian. 


\section{Latar Belakang Masalah}

Chandra Super Store merupakan salah satu pusat perbelanjaan besar di Bandar Lampung, Indonesia. Pada tanggaI 18 Maret 1984 Chandra Supermarket dan Department Store berdiri, berawal dari Chandra Toserba yang bertempat di Jl. Ikan Bawal 33, Teluk Betung, Bandar Lampung. Bekerjasama secara kemitraan, UMKM dan sejumlah perusahaan yang sudah terkenal baik pada skala nasional maupun internasional. Saat ini Chandra teIah memiliki banyak cabang di berbagai daerah di provinsi Lampung, seperti: Bandar Lampung, Metro, Pringsewu, Bandar Jaya. Selain Chandra Super Store, perusahaan kami mendirikan Chandra mini market seperti Chamart Way Halim, yang berIokasi di Jl. Kimaja No.67, Rumah Belanja Chandra serta cabang-cabang di wilayah-wilayah lain.

Hingga saat ini Chamart Way Halim masih dipilih konsumen sebagai pilihan tempat berbelanja. Namun, di samping masih diminati konsumen sebagai pilihan tempat belanja masih terdapat tanggapan mereka yang menyatakan keluhan terhadap Chamart Way Halim. Berikut ini beberapa keluhan dari konsumen yang terdapat pada akun googlemaps Chamart Way Halim: 


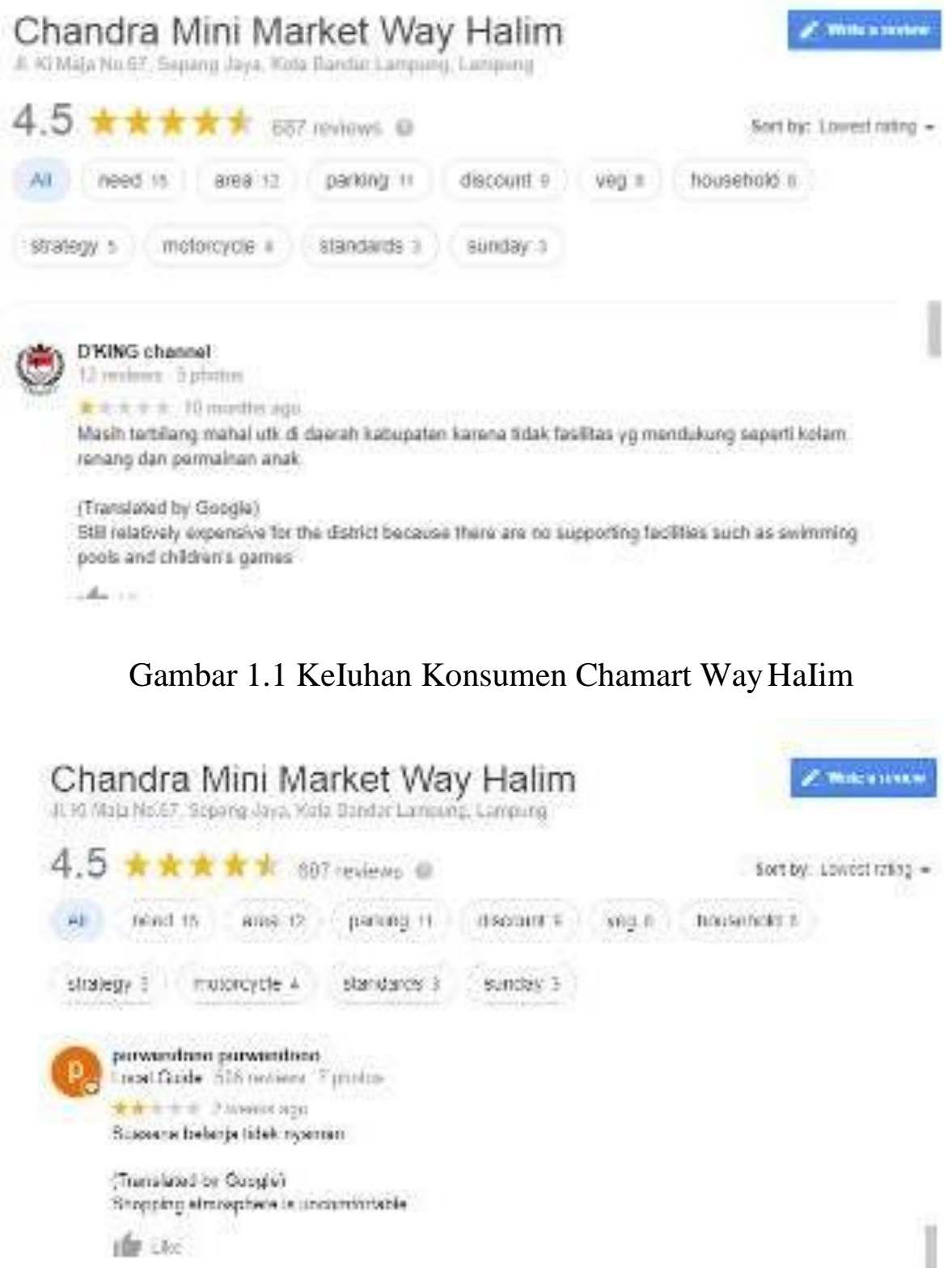

Gambar 1.2 Keluhan Konsumen Chamart Way Halim

Keluhan-keluhan dari para konsumen tersebut perlu diperhatikan oIIeh Chamart Way Halim, karena konsumen yang merasa kecewa akan menjadi sungkan dan bahkan tidak lagi berkunjung kembali untuk melakukan pembelian di Chamart Way HaIim. Selain itu, semakin banyak pusat perbelanjaan Iain yang menjadi pesaing Chamart Way Halim yang tentunya menawarkan kualitas layanan ataupun fasilitas yang baik untuk menarik pengunjung untuk berbelanja. Di kota Bandar Lampung, Chamart Way Halim juga memiliki pesaing seperti Indomart, Alfamart, dan pusat perbelanjaan lainnya yang sama-sama terletak pada lokasi 
yang strategis dan tentunya sama-sama menawarkan berbagai pilihan produk. Hal tersebut, membuat Chamart Way Halim tentunya harus bersaing untuk mendapatkan konsumen.

Berdasarkan uraian tersebut maka peneliti tertarik untuk melakukan penelitian yang berjudul "Pengaruh Store Atmosphere dan Keragaman Produk Terhadap Keputusan Pembelian Pada Chandra Mini Market Way Halim”.

\section{Tujuan Penelitian}

Tujuan yang ingin dicapai daIam penelitian ini adalah :

1. Untuk mengetahui apakah Store Atmosphere berpengaruh terhadap keputusan pembelian.

2. Untuk mengetahui apakah Keragaman Produk berpengaruh terhadap keputusan pembelian.

3. Untuk mengetahui apakah Store Atmosphere dan Keragaman Produk secara bersamasama berpengaruh terhadap keputusan pembelian.

\section{Pengertian Manajemen Pemasaran}

Menurut Kotler dan Keller (2012), mendefinisikan manajemen pemasaran sebagai berikut: "Manajemen pemasaran adaIah mengawasi proses-proses yang ditujukan untuk mengatur keadaan pasar dengan maksud untuk mencapai tujuan organisasi.”

\section{Pengertian Store Atmosphere}

Pengertian Store Atmosphere menurut Berman dan Evan (2007: 454) “Atmosphere refers to the store's physicll characteristics that project an image and draw customer".

\section{Pengertian Keragaman Produk}

Keragaman produk adaIah kelengkapan produk yang menyangkut kedalaman, luas dan kualitas produk yang ditawarkan juga ketersediaan produk tersebut setiap saat di toko (Engels et al, 1995: 258). 


\section{Pengertian Keputusan Pembelian}

Menurut Kotler dan Amstrong (2012), keputusan pembelian adalah tahap dalam proses pengambilan keputusan pembeli dimana konsumen benar benar membeli.

\section{Hipotesis}

Berdasarkan rumusan permasalahan dan kerangka teori yang teIah dijelaskan di atas, maka dapat dirumuskan hipotesis penelitian sebagai berikut :

1) Store Atmosphere diduga berpengaruh signifikan terhadap keputusan pembelian pada Chandra Mini Market Way Halim.

2) Keragaman Produk diduga berpengaruh signifikan terhadap keputusan pembelian pada Chandra Mini Market Way Halim.

3) Store Atmosphere dan Keragaman Produk diduga secara bersama-sama berpengaruh signifikan terhadap keputusan pembelian pada Chandra Mini Market Way Halim.

\section{Desain Penelitian}

Desain penelitian ini berupa desain penelitian Deskriptif. Metode penelitian deskriptif adalah prosedur atau cara pemecahan masalah dengan cara menggambarkan atau melukiskan fenomena, keadaan, peristiwa atau sesuatu yang sedang berlangsung pada saat sekarang berdasarkan pada fakta-fakta yang tampak sebagaimana adanya. Penelitian ini menjelaskan hubungan kausal antara variabel - variabel melalui pengujian hipotesis.

\section{Populasi dan Sampel}

\section{Populasi}

Menurut Sugiono (2009: 223) pengertian populasi yaitu" wilayah generalisasi yang terdiri atas obyek atau subyek yang mempunyai kualitas dan karakteristik tertentu yang ditetapkan oleh peneliti untuk dipelajari dan kemudian ditarik kesimpulannya". Maka populasi dalam penelitian ini adalah semua konsumen Tahun 2019 Chandra Mini Market Way Halim yang berjumlah 3.922 . 
Tabel 3.1 Total Konsumen Chamart Way Halim Tahun 2017-2019

\begin{tabular}{|c|c|}
\hline Tahun & Jumlah Konsumen \\
\hline 2o17 & 3.123 \\
\hline 2018 & 4.231 \\
\hline 2o19 & 3.922 \\
\hline
\end{tabular}

Sumber : Chamart Way Halim

\section{Sampel}

Sampel menurut Sugiyono, (2008:116): "Sampel adalah sebagian dari jumlah dan karakteristik yang dimlliki oleh populasi tersebut".

Teknik sampling daIam penelitian ini adaIah Accidental Sampling Method. Pengertian Accidental Sampling Method menurut Sugiyono (2012:96) yaitu: "Teknik penentuan sampel berdasarkan kebetulan, yaitu siapa saja yang secara kebetulan/insidental bertemu dengan peneliti dapat digunakan sebagai sampel, bila dipandang orang yang kebetulan ditemui itu cocok dengan sumber data. "Jumlah sampel daIam penelitian ini ditentukan berdasarkan rumus Slovin daIam Pratiwi, (2010:56) yaitu:

$$
\mathrm{n}=\frac{\mathrm{N}}{1+\mathrm{Ne}^{2}}
$$

Keterangan :

$\mathrm{n}$ : Ukuran sampel

$\mathrm{N}$ : Ukuran populasi yaitu jumlah total konsumen

e : Nilai kritis

Hasil perhitungan sebagai berikut :

$$
\begin{aligned}
& \mathrm{N}: 3.922 \\
& \mathrm{e}: \mathrm{o}, 1 \mathrm{o} \\
& \mathrm{n}=\frac{\mathrm{N}}{1+\mathrm{Ne}^{2}} \\
& \mathrm{n}=\frac{3.922}{1+3.922(\mathrm{o}, 1 \mathrm{o})^{2}} \\
& \mathrm{n}=\frac{3922}{40,22}
\end{aligned}
$$


$\mathrm{n}=97,51$

Nilai n diperoleh 97,51 dibulatkan menjadi 98. Dari perhitungan diatas maka dapat diketahui bahwa jumlah sampel yang digunakan dalam penelitian ini adalah 98orang.

\section{Analisis Data Kuantitatif}

Analisis data kualitatif adaIah analisis yang dipakai untuk menganalisis data dengan mendeskripsikan data - data yang sudah dikumpulkan seadanya tanpa ada maksud membuat generalisasi dari hasil penelitian.

\section{Analisis Kuantitatif}

Analisis kuantitatif merupakan analisis yang digunakan untuk data-data yang berbentuk angka yang dapat diukur atau dihitung. Tujuan analisis ini adaIah untuk mengetahui seberapa besar pengaruh suatu variabel atau hal terdapat variable lain secara kuantitatif. Analisis ini mengggunakan perhitungan melalui metode statistik dan untuk mempermudah analisis data maka dalam penelitian ini menggunakan sofware SPSS 17.

\section{Uji Validitas Store Atmosphere $(\mathrm{X1})$}

Uji validitas digunakan untuk menguji sejauh mana ketepatan alat pengukur dapat mengungkapkan konsep gejala/kejadian yang diukur. Item kuisioner dinyatakan valid apabiIa nilai $r$ hitung $>\mathrm{r}$ tabel $(0,198)$.

\section{HasiI Uji Validitas Store Atmosphere (X1)}

\begin{tabular}{|c|c|c|c|c|}
\hline Pertanyaan & NiIai r Hitung & NiIai r tabeI & $\mathrm{N}$ & KesimpuIan \\
\hline Pernyataan 1 & 0.452 & 0,198 & 98 & Valid \\
\hline Pernyataan 2 & 0.430 & 0,198 & 98 & Valid \\
\hline Pernyataan 3 & 0.624 & 0,198 & 98 & Valid \\
\hline Pernyataan 4 & 0.536 & 0,198 & 98 & Valid \\
\hline Pernyataan 5 & 0.634 & 0,198 & 98 & Valid \\
\hline Pernyataan 6 & 0.678 & 0,198 & 98 & Valid \\
\hline Pernyataan 7 & 0.669 & 0,198 & 98 & Valid \\
\hline Pernyataan 8 & $0.7 \mathrm{o} 4$ & 0,198 & 98 & Valid \\
\hline Pernyataan 9 & $0.7 \mathrm{o6}$ & 0,198 & 98 & Valid \\
\hline Pernyataan 10 & 0.759 & 0,198 & 98 & Valid \\
\hline
\end{tabular}

Sumber: Data Diolah, 2020 
Dari Hasil uji statistik diatas didapatkan sebanyak 10 item pertanyaan yang mempunyai $r$ hitung $>r$ tabel $=0,198$ sehingga seIuruh item pertanyaan valid.

\section{Uji Validitas Keragaman Produk(X2)}

Uji validitas digunakan untuk menguji sejauh mana ketepatan alat pengukur dapat mengungkapkan konsep gejala/kejadian yang diukur. Item kuisioner dinyatakan valid apabiIa nilai $r$ hitung $>r$ tabel $(0,198)$.

\section{HasiI Uji Validitas Keragaman Produk (X2)}

\begin{tabular}{|c|c|c|c|c|}
\hline Pertanyaan & NiIai r Hitung & NiIai r tabeI & $\mathrm{N}$ & KesimpuIan \\
\hline Pernyataan 1 & 0.769 & 0,198 & 98 & Valid \\
\hline Pernyataan 2 & 0.765 & 0,198 & 98 & Valid \\
\hline Pernyataan 3 & 0.753 & 0,198 & 98 & Valid \\
\hline Pernyataan 4 & 0.789 & 0,198 & 98 & Valid \\
\hline Pernyataan 5 & 0.788 & 0,198 & 98 & Valid \\
\hline Pernyataan 6 & 0.803 & 0,198 & 98 & Valid \\
\hline Pernyataan 7 & 0.739 & 0,198 & 98 & Valid \\
\hline Pernyataan 8 & 0.825 & 0,198 & 98 & Valid \\
\hline Pernyataan 9 & 0.768 & 0,198 & 98 & Valid \\
\hline Pernyataan 10 & 0.830 & 0,198 & 98 & Valid \\
\hline
\end{tabular}

Sumber: Data Diolah, 2020

Dari Hasil uji statistik diatas didapatkan sebanyak 0o item pertanyaan yang mempunyai $r$ hitung $>\mathrm{r}$ tabel $=0,198$ sehingga seluruh item pertanyaan valid.

\section{Uji Validitas Keputusan Pembelian (Y)}

Uji validitas digunakan untuk menguji sejauh mana ketepatan alat pengukur dapat mengungkapkan konsep gejala/kejadian yang diukur. Item kuisioner dinyatakan valid apabila nilai $r$ hitung $>\mathrm{r}$ tabel $(0,198)$.

\section{HasiI Uji VaIiditas Keputusan PembeIian (Y)}

\begin{tabular}{|c|c|c|c|c|}
\hline Pertanyaan & Nilai r Hitung & Nilai r tabel & N & Kesimpulan \\
\hline Pernyataan 1 & 0.532 & 0,198 & 98 & Valid \\
\hline
\end{tabular}




\begin{tabular}{|c|c|c|c|c|}
\hline Pernyataan 2 & 0.724 & 0,198 & 98 & Valid \\
\hline Pernyataan 3 & 0.739 & 0,198 & 98 & Valid \\
\hline Pernyataan 4 & 0.805 & 0,198 & 98 & Valid \\
\hline Pernyataan 5 & 0.721 & 0,198 & 98 & Valid \\
\hline Pernyataan 6 & 0.700 & 0,198 & 98 & Valid \\
\hline Pernyataan 7 & 0.727 & 0,198 & 98 & Valid \\
\hline Pernyataan 8 & 0.781 & 0,198 & 98 & Valid \\
\hline Pernyataan 9 & 0.708 & 0,198 & 98 & Valid \\
\hline Pernyataan 10 & 0.726 & 0,198 & 98 & Valid \\
\hline
\end{tabular}

Sumber: Data Diolah, 2020

Dari Hasil uji statistik diatas didapatkan sebanyak 10 item pertanyaan yang mempunyai $r$ hitung $>\mathrm{r}$ tabel $=0,198$ sehingga seluruh item pertanyaan valid.

\section{Uji Reliabilitas}

TabeI 4.1 Uji

Realiabilitas Reliability

Statistics

\begin{tabular}{|c|c|c|}
\hline Varibel & Cronbach's Alpha & Realibility \\
\hline X1 & .820 & Reliabel \\
\hline X2 & .930 & Reliabel \\
\hline Y & .894 & Reliabel \\
\hline
\end{tabular}

Sumber: Data Diolah, 2020

Dari hasil uji Reliabilitas di atas di dapat nilai alpha nya $>0,60$ maka kuisioner penelitian ini dinyatakan reliabeI. ini berarti bahwa alat ukur yang digunakan dalam penelitian ini sudah memiliki kemampuan untuk memberikan hasil pengukuran yang konsisten dalam mengukur gejala yang sama. 
Analisis Regresi Linier Berganda

Coefficients $^{\mathbf{a}}$

\begin{tabular}{|c|l|l|l|l|c|}
\hline \multirow{2}{*}{ Model } & \multicolumn{2}{|l|}{$\begin{array}{l}\text { Unstandardized } \\
\text { Coefficients }\end{array}$} & $\begin{array}{l}\text { Standardiz } \\
\text { ed } \\
\text { Coefficien } \\
\text { ts }\end{array}$ & t Sig. \\
\cline { 2 - 6 } & B & Std. Error & $\begin{array}{l}\text { Bet } \\
\mathrm{a}\end{array}$ & \\
\hline
\end{tabular}




\begin{tabular}{|c|c|c|c|c|c|c|}
\hline \multirow[t]{3}{*}{1} & (Constant) & 6.694 & 5.397 & & $1.24 \mathrm{o}$ & .218 \\
\hline & $\begin{array}{l}\text { Store } \\
\text { Atmosphere }\end{array}$ & .299 & .116 & .228 & $2.57 \mathrm{~d}$ & .012 \\
\hline & $\begin{array}{l}\text { Keragam } \\
\text { an } \\
\text { Produk }\end{array}$ & .488 & .100 & .432 & 4.862 & .000 \\
\hline
\end{tabular}

a. Dependent Variable: Keputusan Pembelian

\section{Koefisien Determinasi}

Model Summary

\begin{tabular}{|r|r|r|r|r|}
\hline ModeI & \multicolumn{1}{|c|}{$\mathrm{R}$} & $\mathrm{R}$ Square & $\begin{array}{c}\text { Adjusted } \\
\mathrm{R} \\
\text { Square }\end{array}$ & $\begin{array}{l}\text { Std. Error of } \\
\text { the } \\
\text { Estimate }\end{array}$ \\
\hline 1 & $\begin{array}{r}.508 \\
\mathrm{a}\end{array}$ & .258 & .243 & 5.147 \\
\hline
\end{tabular}

a. Predictors: (Constant), Keragaman Produk, Store Atmosphere

Sumber: Data Diolah dengan SPSS23, 2020

\section{Uji Hipotesis}

Uji Hipotesis Secara Parsial atau Uji t

\subsection{Uji Hipotesis Slcara Parsial atau Uji t}

Coefficients $^{\mathbf{a}}$

\begin{tabular}{|c|c|c|c|c|c|c|}
\hline \multirow[t]{2}{*}{ Model } & & \multicolumn{2}{|c|}{$\begin{array}{l}\text { Unstandardized } \\
\text { Coefficients }\end{array}$} & $\begin{array}{l}\text { Standardiz } \\
\text { ed } \\
\text { Coefficien } \\
\text { ts }\end{array}$ & \multirow{2}{*}{$\mathrm{t}$} & \multirow{2}{*}{ Sig. } \\
\hline & & B & Std. Error & $\begin{array}{c}\text { Bet } \\
\mathrm{a}\end{array}$ & & \\
\hline \multirow[t]{3}{*}{1} & (Constant) & 6.694 & 5.397 & & $1.24 \mathrm{o}$ & .218 \\
\hline & $\begin{array}{l}\text { Store } \\
\text { Atmosphere }\end{array}$ & .299 & .116 & .228 & $2.57 \mathrm{~d}$ & .012 \\
\hline & $\begin{array}{l}\text { Keragam } \\
\text { an } \\
\text { Produk }\end{array}$ & .488 & .100 & .432 & 4.862 & .000 \\
\hline
\end{tabular}

a. Dependent Variable: Keputusan Pembelian

Sumber: Data Diolah SPSS23, 2020 


\section{Uji Hipotesis Store Atmosphere terhadap Keputusan Pembelian}

Berdasarkan uji hipotesis diatas di dapat thitung variabel Store Atmosphere sebesar 2,50 lebih besar dibandingkan dengan $\boldsymbol{t}$ tabel yaitu 1,985 dengan tingkat signifikan 0,012 karena probality jauh lebih kecil 0,05 maka Store Atmosphere berpengaruh terhadap Keputusan Pembelian, berarti Ho ditolak dan Ha diterima. Dengan demikian hipotesis pertama "Store Atmosphere berpengaruh terhadap Keputusan Pembelian pada Chandra Mini Market Way Halim" diterima.

\section{Uji Hipotesis Keragaman Produk terhadap Keputusan PembeIian}

Berdasarkan uji hipotesis diatas di dapat thitung variabel Keragaman Produk sebesar 4,862 lebih besar dibandingkan dengan $\boldsymbol{t}$ tabel yaitu 1,985 dengan tingkat signifikan o,ooo karena probality jauh lebih kecil dari o,o5 maka Keragaman Produk berpengaruh terhadap Keputusan Pembelian, berarti Ho ditolak dan Ha diterima.

Dengan demikian hipotesis kedul "Keragaman Produk berpengaruh terhadap Keputusan Pembelian pada Chandra Mini Market Way Halim” diterima.

\section{Uji Hipotesis Anova atau Uji F}

\section{Uji Hipotesis Secara Simultan atau Uji F}

\begin{tabular}{|c|c|c|c|c|c|}
\hline \multicolumn{6}{|c|}{$\mathbf{A N o V A}^{b}$} \\
\hline Model & $\begin{array}{l}\text { Sum of } \\
\text { Squares }\end{array}$ & $\mathrm{d}$ & $\begin{array}{l}\text { Mean } \\
\text { Square }\end{array}$ & $\mathrm{F}$ & Sig. \\
\hline $\begin{array}{c}{ }^{1} \text { Regression } \\
\text { Residual } \\
\text { Total }\end{array}$ & $\begin{array}{c}875.816 \\
2516.684 \\
3392.500\end{array}$ & $\begin{array}{r}2 \\
95 \\
97\end{array}$ & $\begin{array}{r}437.908 \\
26.491\end{array}$ & $\begin{array}{l}16.53 \\
o\end{array}$ & .000 \\
\hline
\end{tabular}

a. Predictors: (Constant), Keragaman Produk, Store Atmosphere

b. Dependent Variable: Keputusan Pembelian

Sumber: Data Diolah SPSS23, 2020

Dari uji anova atau $\mathrm{F}$ test didapat $\mathrm{F}$ hitung sebesar 16,530 dengan tingkat signifikan 0,000 karena probability jauh lebih keciI dari 0,05 maka Store Atmosphere dan Keragaman Produk secara bersama-sama berpengaruh terhadap Keputusan Pembelian, berarti Ho ditolak Ha diterima. 
Dengan demikian hipotesis ketiga : "Store Atmosphere dan Keragaman Produk secara bersama-sama berpengaruh signifikan terhadap Keputusan Pembelian pada Chandra Mini Market Way Halim" dapat diterima.

\section{KesimpuIan}

Berdasarkan hasil analisis data, maka dapat disimpulkan bahwa Store Atmosphere dan Keragaman Produk berpengaruh positif terhadap Keputusan Pembelian. Simpulan tersebut ditunjukkan dari temuan-temuan hasil analisis sebagai berikut :

1. Store Atmosphere mempunyai pengaruh positif signifikan terhadap Keputusan Pembelian pada Chandra Mini Market Way Halim. Artinya Store Atmosphere pada Chandra Mini Market Way Halim sudah baik.

2. Keragaman Produk mempunyai pengaruh positif signifikan terhadap Keputusan Pembelian pada Chandra Mini Market Way Halim. Artinya Keragaman produk Chandra Mini Market Way Halim sudah baik.

3. Store Atmosphere dan Keragaman Produk mempunyai pengaruh positif dan signifikan secara bersama-sama terhadap Keputusan Pembelian pada Chandra Mini Market Way Halim. Artinya Store Atmosphere dan Keragaman Produk pada Chandra Mini Market Way Halim sudah baik.

\section{Saran}

Berdasarkan hasil analisa data secara kualitatif dan kuantitatif terdapat beberapa hal yang perlu direkomendasikan kepada Chandra Mini Market Way Halim dalam rangka peningkatan Keputusan Pembelian agar lebih Setuju dari keadaan saat ini antara lain:

1. Diharapkan lebih teliti dan cermat terhadap pemilihan dan penentuan Store Atmosphere supaya tepat sasaran serta tercapainya tujuan di Chandra Mini Market Way Halim

2. Dalam rangka meningkatkan Keragaman Produk diperlukan Chandra Mini Market Way Halim sebaiknya tetap memperbanyak Keragaman Produk yang dapat menarik minat konsumen daIam mengambil keputusan pembelian. 


\section{DAFTAR PUSTAKA}

Agusta, Rifki Arga. 2o13. "Pengaruh Store Atmosphere dan Word of Mouth terhadap Minat Beli Konsumen (Studi pada Konsumen The House of Raminten Yogyakarta)". Skripsi. Yogyakarta: Universitas Negeri Yogyakarta.

Banat, A., \& Wandebori, H. S. T. 2012. Store Design and Store Atmosphere Effect on Customer Sales per Visit Economics, Management and Behavioral Sciences. New Jersey: Prentice Hall.

Berman, Barry, and Joel R. Evans, 20o7, Retail Management, New Jersey: Prentice Hall.

Chang, Hsin Hsin, Hsu Che-Hao dan Chung, Shu Hsia. 2oo8. The Antecedents and

Consequences of Brand Equity in Service Markets. Asia Pasific Management Review, 13(3).

Daryanto. 2o11. Sari Kuliah Manajemen Pemasaran. Bandung : PT. Sarana Tutorial Nurani Sejahtera.

Ghozali, Imam, 20o9. Aplikasi Analisis Multivariate Dengan Program SPSS, Edisi Keempat, Penerbit Universitas Diponegoro.

Hani Handoko. 2o1o. Manajemen Personalia \& Sumber Daya Manusia. Edisi kedua. Yogyakarta : BPFE UGM.

Hawkin., et al., 2ooo, Customer Behavior, Copy Right by Mc, Grow Hill Companies,Inc

Kotler, Philip and Kevin Lane Keller. 2oo9. Manajemen Pemasaran. Edisi 13. Jilid 1. Jakarta : Erlangga.

Kotler, Philip and Kevin Lane Keller. 2o12. Marketing Management. Edisi 14. New Jersey: Prentice-Hall Published. 